\title{
Workplace Suicide and States of Denial: The France Télécom and Foxconn Cases Compared
}

\author{
Sarah Waters
}

School of Languages, Cultures and Societies, University of Leeds, Leeds, United Kingdom, S.a.waters@Leeds.ac.uk

\begin{abstract}
Workplace suicides are sharply on the rise and reflect a generalised deterioration in working conditions across the globalised economy. Despite their growing prevalence, workplace suicides are subject to specific modes of repression that tend to keep them hidden from public view. Suicides and their social recognition threaten the vested interests of corporate and political elites by giving material embodiment to relations of production in the form of extreme human suffering. This article focuses on 'suicide waves' at two distant corporations in the information and communications sector: in France, the telecoms provider, France Télécom (rebranded Orange in 2013) and in China, electronics supplier, Foxconn. Drawing on Stanley Cohen's notion of 'states of denial', the article examines the tactics used by business and political elites in an effort to keep the suicides concealed. These include discourses that denied the suicides, individualised their causes and repressive tactics intended to control information and impede investigations. Recognising workplace suicides and the forms of repression that seek to occlude them is crucial if we are to confront the profound human costs of a new international division of digital labour on lived experiences of work.
\end{abstract}

Keywords: Suicide, France Télécom, Foxconn, digital labour, workplace

\section{Introduction}

When confronted with events that are deeply unsettling, disturbing or traumatic, societies tend to enter "states of denial" that disavow the reality of events or push them to one side: this can lead to "an unspoken collusion to ignore (or pretend to ignore?) the whole subject" (Cohen 2001, xi). The phenomenon of workplace suicides, whereby individuals in the face of extreme pressures at work choose to take their own lives within the ordinary and quotidian setting of today's workplaces, brings to the fore experiences of trauma that are difficult to contemplate or imagine. Workplace suicides are sharply on the rise within a range of occupations and economic sectors across distant sites of the globalised economy. This paper focuses on 'suicide waves' in two corporations within the information and communication technology sector: the French telecoms provider France Télécom, rebranded Orange in 2013, and the Taiwanese corporation Foxconn, based in China. Despite sharp differences in forms of labour, material conditions and social protection in these two corporations, within a concentrated period of time groups of employees were placed under such intense pressure that they chose to take their own lives. In 2012, the chief executive of France Télécom, Didier Lombard, and six other executives were placed under judicial investigation in the case of 35 suicides by employees at the company in 2008 and 2009 (Waters and Chan 2016). At Foxconn in 2010, 18 young migrant workers attempted suicide, resulting in 14 deaths and 4 who survived with 
crippling injuries (Chan and Pun 2010) These two cases form part of a broader international phenomenon of an increase in "economic suicides", particularly in the period since the 2008 economic crisis (Stuckler and Basu 2013; Reeves, McKee and Stuckler, 2014).

Beyond a collective instinct towards denial which tends to push this issue to one side, workplace suicide is also subject to specific forms of repression that seek to keep it hidden from public view. Workplace suicide is subject to a "negationist tendency" that disavows the connections between the suicidal act and the workplace (Dejours 2014). The "collective denial" and "rule of silence" that prevails on this question tends to keep its social and structural causes concealed (Alemanno and Cabdedoche 2011, 33, 30). Such 'states of denial' serve the vested interests of business and political elites. On the one hand, suicides and their social recognition jeopardise businesses whose corporate reputation and financial interests are undermined by the media exposure of suicides. In a digital economy where gadgets are presented as slick, carefree, aesthetic commodities that are disconnected from any links to messy corporeal realities, suicide constitutes a brutal intrusion of flesh and blood. These suicides give material embodiment to often hidden relations of production in the form of unspeakable pain, trauma and distress. At France Télécom, suicides placed corporate bosses under close scrutiny and the company's chief executive was forced to resign. Furthermore, many families pursued litigation against the company, obliging it to pay vast sums in financial compensation (Decèze 2008; Du Roy 2009). In China, workplace suicides threatened the corporate reputation of both Foxconn and American multinational Apple, for whom Chinese workers were producing iPhones in factories characterised by "sweatshop conditions" (Hesseldahl 2006). On the other hand, suicides threaten political elites whose policies of economic liberalisation and labour market reform have defined conditions in the "restructured new workplaces" in which suicides take place (Danford, Richardson and Upchurch 2003, 26). In France, suicides undermined the reputation of the state, which partially owned France Télécom, and which defined the employment status of the public service employees who took their own lives. In China, suicides called into question the role of the state which had facilitated and promoted Foxconn's expansion and had helped to supply it with a pool of cheap migrant labour. Because of the high political and economic stakes involved, suicides in these companies were subject to repressive tactics that sought to keep them hidden.

Recognising, documenting and making visible the phenomenon of workplace suicides is crucial if we are to take account of the profound human and social consequences of a new international division of labour on lived experiences of work. For Sassen, the global economic order is too complex, abstract and elusive to grasp as a systemic whole. Instead, we need to examine this order from the vantage point of the "systemic edge" where it comes into contact with human bodies and gives rise to "astounding elementary brutalities" (2014, 211 and 220). Examining workplace suicides can help make sharply visible some of the generalised conditions of work that define today's globalised information age. Social recognition can also help to counter processes of occlusion that sublimate and fetishise products while hiding the human labour that has produced them. As critics have shown, this occlusion is particularly evident in the digital economy, where labour conditions are often concealed behind the immediacy, high speed and aesthetic appeal of hi-tech gadgets (Sandoval 2013; Fuchs 2014; Dyer-Witheford 2014). This paper aims to examine the modes of repression, obfuscation and disavowal that were used by corporate and political elites at Foxconn and France Télécom in relation to the 
suicides that took place in these companies. These included discourses that aimed to deny, individualise or rationalise the suicides and that either blamed the individual as being responsible for his or her own death or rationalised the suicides in relation to higher and ineluctable economic forces. Elites also used specific modes of repression that sought to control information on the suicides, impede their investigation or censor the media. Yet, in both cases, labour rights activists succeeded in breaking the censorship in place, forcing suicides into the open and exposing them to widespread media scrutiny. Behind every suicide is a story of immense personal trauma, and yet workplace suicides have also become a collective phenomenon and are a powerful indictment of contemporary conditions of work.

\section{Suicide and global capitalism}

Writing at the close of the nineteenth century, French sociologist Emile Durkheim argued that suicide is a social phenomenon that transcends individual circumstances and reveals the fundamental nature of the social order itself. Durkheim's work, and later that of Maurice Halbwachs (1930), helped to define a sociological tradition in the study of suicide that examines its causes by turning outwards towards social conditions external to the individual. Recent studies carried out in France (Dejours and Bègue 2009; Waters 2015), the United States (Tiesman et al. 2015), Australia (Routley and Ozanne-Smith 2012), Japan (Kawanishi 2008), China (Chan 2013), India (Agrawal 2014) and Taiwan (Chen 2014) point to a sharp rise in workplace suicides within the context of a generalised deterioration in working conditions. Suicides are not confined to particular workplaces, occupations or places, and recent 'suicide waves' have affected groups as diverse as Indian farmers, Chinese assembly-line workers or Australian miners, as well as white-collar workers such as French engineers, Japanese managers and British bankers. In fact, the diversity of recent suicide cases seem to challenge the assumptions of immaterial labour theory and the binary it creates between material labour, linked to conditions of physical exploitation and disciplinary regimentation, and immaterial labour, characterised by autonomy, freedom and creativity. Recent suicides manifest conditions of extreme suffering in both manual and cognitive occupations and challenge this dichotomy between body and mind. In the United States, workplace suicides decreased between 2003 and 2007, but then rose sharply in the following years (Tiesman et al. 2015). In Japan, karo-jisatu or suicide by overwork is treated as an urgent public health issue and, under a 2014 law, the government is obliged to take measures to prevent it from taking place (North 2014). A recent Australian study found that $17 \%$ of suicides in Victoria from 2000-2007 were work-related (Australian Medical Association 2014). In France, the government created a National Observatory of Suicide in 2013 to tackle rising suicide rates, not only in the workplace, but across the whole of French society. Workplace suicide is a new phenomenon in historical terms, and apart from Japan, there are few documented cases prior to the 1980s. Work and the workplace have traditionally acted as a space for social integration that binds the individual to society through bonds of social class and communal labour. Whilst Marxists identify the workplace as a site of capitalist exploitation, it is also seen as a space that fosters social relationships and provides a foundation for solidarity and class identity. For Durkheim, the workplace constitutes an idealised form of social relationship and is a space in which suicide is least likely to occur. In the final chapter of Suicide (1930 [1897]), Durkheim even suggests that the problem 
of suicide could be addressed by improving forms of social integration and exchange in the workplace.

Why does contemporary work, or conditions of work, push some individuals to take their own lives? What do rising workplace suicides tell us about conditions of human labour within today's globalised economy? A number of critics have sought to establish connections between a historical shift towards global capitalism and new forms of endemic violence within the workplace. For Dejours $(1998 ; 2015)$ the workplace has become a prime site of social suffering where the brutalities of the economic order are most keenly felt. He portrays a workplace in which workers are routinely engaged by management in acts of cruelty designed to help eliminate those who are deemed to be weak or unproductive. This "banalisation of evil" has transformed the workplace from a space of social solidarities to one of violence and elimination. For Sassen (2014), global capitalism is driven by new logics of expulsion that strive to push out those who are deemed unproductive, unfit or surplus to economic needs. Whereas the post-war Fordist economy was inclusive and brought people into the collective spaces of social life, global capitalism tends to forcibly eject them. Her book explores the way in which neoliberal economics engages with human bodies in the everyday, giving rise to normalised forms of systemic violence. Similarly, Giroux and Evans (2015) argue that the contemporary economic order is driven by a "politics of disposability" that consigns humans to excess and subjects them to hidden forms of violence and brutality. Workers are dehumanised and treated as factors of adjustment, to be disposed of when economic interests require. For these critics, social violence in the workplace is embedded in the logic of instrumental rationality and the appeal to progress that drives neoliberal globalisation.

Beyond generalised forms of violence, some studies have established a connection between the contemporary economic order and rising suicide rates internationally. Hence Stuckler and Basu signal a sharp rise in "economic suicides" in the context of the economic crisis and in particular, the shift towards austerity politics across many European countries (2013). Similarly, for Marxist theorist Franco Bifo Berardi, suicide manifests the nature of contemporary finance capitalism in which relentless competitivity and hyper-connectivity have devastating effects on mental health: "I write about spectacular murderous suicides because these killers are the extreme manifestation of one of the main trends of our age. I see them as the heroes of an age of nihilism and spectacular stupidity: the age of financial capitalism" $(2015,3)$. Furthermore, some studies have drawn links between the individual act of suicide and recent transformations in workplace conditions or management practices within advanced industrial societies. One study shows how neoliberal workplace transformations and in particular, the rise of precarious employment, have had deleterious effects on the mental health of workers, with rising cases of chronic stress, burn-out, depression and suicide (Benach et al. 2014). Another study that analyses testimonies written by suicide victims in the French workplace shows that individuals typically attribute their own suicides to extreme workplace pressures, such as work intensification, insecure contracts, chaotic restructuring or tyrannical management (Waters 2016).

The two 'suicide waves' examined here both took place in corporations within the information and communication technology sector, where workers draw on advanced technologies to provide products and services associated with the mobile phone. The information and communications sector is characterised by a wide variety of forms of labour, from "creative labour" (Brouillette 2009), "free labour" (Terranova 
2000), to survival labour (Qiu, Gregg and Crawford 2014) or even slave labour (Qiu 2016). These forms of "digital labour" are defined not by a common occupation, but by a "commonality of exploitation" (Fuchs 2014, 4) across different sites of the globalised economy. Whilst workers in France Télécom and Foxconn belong to the same economic sector and engage in similar production and consumption processes, they are characterised by highly polarised models of labour that reflect an "international division of digital labour" (Ibid., 286). France Télécom's 102254 employees are principally 'knowledge workers': highly-skilled engineers, technicians and managers who draw on their cognitive and social skills to produce new technologies in the telephone and Internet sectors. They can be seen to typify the features of immaterial labour that "produces the informational and cultural content of the commodity" (Lazzerato 1996, 133). The majority of these workers are public service employees who benefit from excellent material conditions and social benefits, stable jobs, generous pensions and extensive formal working rights. Foxconn's employees, by contrast, are semi-skilled assembly-line workers who engage in repetitive manual work in poor conditions, with limited social protection and weak union representation. Foxconn employs over a million workers in China who assemble and manufacture electronics gadgets for the world's richest corporations, including Apple, Samsung, Nokia, Dell and Panasonic. Foxconn has attracted intense interest from labour rights activists and scholars and is seen to represent the "dirty secret" of supply chains in newly industrialising countries (DyerWitheford, 2014, 169). Yet, despite these marked differences in forms of labour, with an opposition between manual and mental forms of work, workers in both corporations found themselves pushed to the limits of human endurance to the extent that some chose to take their own lives.

\subsection{France Télécom}

In July 2016, French prosecutors announced that Didier Lombard, former chief executive of France Télécom, and six other executives may face criminal charges in relation to 35 suicides by employees at the company in 2008 and 2009. They are accused not of targeting individual employees, but of pursuing a management strategy across the whole company, based on harcèlement moral or psychological bullying (Marlowe 2016). The France Télécom suicides were the tragic outcome of management strategies, put in place following the company's privatisation and restructuring, that were intended to relaunch the company as a leading global telecoms provider and at the same time, implement a massive job cuts programme. The judicial investigation into the suicides revealed that management put in place tactics intended to destabilise the working lives of the entire workforce and thereby push employees to leave the company 'voluntarily'. According to the Paris prosecutor's 193-page requisition, which was signed on 22 June 2016, approximately 4,000 executives were trained each year in techniques that would exert maximum pressure and "push their colleagues to their limits" (Cazi 2014). A survey carried out by a trade union observatory in 2007 based on questionnaires completed by 3,200 employees revealed that two out of three employees were experiencing work-related stress (Du Roy 2009). A subsequent study by researchers into working conditions at the company described the management's "programmed mistreatment" of employees (Burgi, Crinon and Fayman 2008). Some were subjected to such intense management pressures that they chose to take their own lives. 12 France Télécom employees took their own lives in 2008; 19 in 2009; 27 in 2010; and 11 in 2011. Despite a new agreement on workplace conditions negotiated 
with the trade unions, there has been a renewal of suicides recently with 11 cases in 2013 and 10 suicides in 2014 (Waters 2014).

French telecommunications has a long history as a state enterprise and since 1889 had been governed directly by a government ministry in Paris. The company was characterised by a strong public service culture based on values of fairness and equality, and its purpose was to provide an equitable telephone service to all citizens across the national territory. The company's privatisation in 1997 marked a rupture with this public service tradition and the rise of a new finance-based logic driven by a need to increase shareholder value on international financial markets. Company bosses sought to rid France Télécom of a cumbersome public sector identity and transform it into a dynamic player in the "planetary Monopoly game of telecommunications" (Du Roy 2009, 79). Management strategy aimed to assert France Télécom's position in a highly competitive market by increasing profits through the sale of shares on financial markets, engaging in a series of mergers and acquisitions (including UK mobile phone provider Orange) and developing cuttingedge technologies, particularly in the lucrative Internet sector. However, following chief executive Michel Le Bon's poor leadership and his frenzied acquisition of overseas companies, the company accumulated vast debts and had to be bailed out by public funds. By 2001, France Télécom was the most indebted company in the world and Moody's downgraded its shares to the status of junk bonds (Du Roy 2009). This meant that when Didier Lombard took over as chief executive in 2005, he had an overriding priority: to reduce the company's debts through massive staff cuts. His "Next" restructuring plan (2005-2008) set its target to cut 22,000 jobs in the space of three years and to push another 14,000 employees to change positions. A statement that he made at a board meeting which was later leaked to the press set the tone for the restructuring process: "I'll make them leave, one way or another, through the window or out the door" (Cazi 2014). As the majority of staff were public service employees and couldn't be legally fired, management resorted to more insidious psychological tactics to push them to leave the company.

France Télécom employees are highly-skilled and well-paid "knowledge workers" (McKercher and Mosco 2007; Moulier Boutang 2011) who benefit from excellent social protection and extensive workplace rights. Its workforce is characterised by considerable autonomy, professional status and creative participation in the company's technological innovations. Until recently, the company employed a stable and long-term workforce; $61 \%$ of employees were over 45 years of age and had worked at the company for two to three decades (Technologia 2010). As part of a 2003 agreement with trade unions, the company's fonctionnaires, who made up 70\% of its workforce, were allowed to keep their public service status, which included job security, pension benefits and social protection. Yet in the wake of privatisation this stable and well-paid workforce was increasingly perceived by management as a significant obstacle to the company's economic and financial ambitions. Suicides at France Télécom were not a tragic accident or an aberration in a smooth-running business model, but were the likely outcome of a management strategy that sought to eliminate the superfluous costs that were identified with an immobile, regulated and seemingly privileged workforce (Waters 2014). One of the key policies put in place under the Next plan was forced redeployment, whereby employees were pushed to change jobs on an almost continuous basis or move to new branches in distant cities at short notice. Relocations were often chaotic and unplanned, with workers being forced to move to a new branch only to have that branch close down, requiring them to move elsewhere. In many cases, staff were transferred from highly 
skilled roles as engineers or technicians to low-skilled commercial positions in shops or call centres. Some were given impossible targets or allocated an unmanageable workload. Others were humiliated in front of colleagues or sent a barrage of e-mails by their line manager. Suicides were highest amongst male engineers or technicians in their fifties who had worked for the company for over 30 years but had been pushed to join the 'front line' of the company in one of its call-centres, as part of a policy of forced redeployment. They went from a position of considerable autonomy and professional status to a situation in which they had to read a script from a headset, sell products over a phone and ask permission to use the toilet.

Many suicidal individuals at France Télécom left letters, subsequently published in the French press, that explained the causes of their self-killing and pointed the finger at bosses. These letters bear witness to conditions of unbearable stress linked to chaotic restructuring, work intensification, management bullying and demotion. In one well-publicised case, a 53-year-old technician, who had been redeployed into a call-centre from his existing role monitoring satellite communications when the centre where he worked had been shut down, threw himself under a train on 2 July 2008. Prior to his suicide, he sent a letter to his trade union representative that emphasised his frustration with his new role for which he had no professional experience or training: "You know, I could no longer bear to be in this hell, spending hours in front of a screen like a mechanical puppet faced with the determination of some people to let us die like dogs". He criticises management tactics and asks the trade union to let others know what is going on: "If you could speak about this or escalate it, so that others know and realise what this reckless lot is prepared to do to get people to leave" (Decèze 2008, 29-30). In another case, a 57-year-old management controller and father of four set fire to himself upon arriving in the car park outside the France Télécom office building where he worked near Bordeaux on the morning of 26 April 2011. Following his suicide, an open letter that he had written to company bosses in September 2009 was published in the French press in which he criticises a "management by terror" that pressurises employees and makes them feel guilty for resisting organisational change. He identifies himself amongst the group of workers over 50 years of age who were being forcibly redeployed into new posts: "I am part of this segment. I am surplus to requirements (...) Suicide has become a solution" (Lacaze 2011). The destabilising effects of restructuring in the workplace are reaffirmed in another letter published in the press by a colleague of a France Télécom employee who killed himself on 17 May 2008, in which he states: "We live in a situation of permanent stress, pressure, restructuring and doubts about our future" (Decèze 2008, 30-31). The France Télécom suicides can be seen to manifest new forms of suffering that characterise knowledge work in the information and communications sector and that are linked to intense psychological pressures. Those who committed suicide benefitted from excellent material and social conditions, and had job security and social protection. Yet these highly-skilled employees, few of whom had any prior history of mental illness or depression, were placed under such intense pressure by managers in pursuit of economic gain that some resorted to self-killling (Dejours and Bègue, 2009).

\subsection{Foxconn}

Alongside the immaterial "cognitive labour" (Moulier Boutang 2011) that characterises work at France Télécom, the digital economy draws on the mass material labour of billions of workers who are concentrated within supplier factories located primarily in low-cost countries in Asia. Taiwanese corporation Foxconn, 
which is based in China and produces electronic gadgets for some of the world's richest corporations, has been seen to represent the "dark side" (Sandoval 2013) of an information age that is built "on the backs of tens of millions of Chinese workers" (Zhao and Duffy 2008, 229). Having a total workforce of over one million in China alone, Foxconn now dominates the global market by producing half of the world's electronic goods. Foxconn exemplifies a model of labour based on "subcontracting exploitation" in which powerful corporations outsource their labour supply to newly industrialising countries such as China where there is a vast pool of cheap, disciplined and non-unionised labour (Chan, Pun and Selden 2015, 76). Researchers have shown that this outsourcing of material labour has generated immense profits for corporations which can harness labour towards the needs of cheap, efficient and just-in-time production (Pun, Chan and Chan 2010; Pun and Chan 2012; Chan, Pun and Selden 2015). In the production of the iPhone, Apple has captured $58.5 \%$ of the value of the product, whilst labour costs account for the smallest share at $1.8 \%$ of value (Pun et al. 2016). Whilst Apple is now the most profitable corporation in the world and Foxconn is the world leader in the electronics manufacturing sector, their economic success is built on the sacrifice of the basic rights and humane treatment of Chinese workers. Researchers have shown how the dominance of Apple and the intense pressure it exerted on Foxconn to lower its prices and meet production deadlines resulted in a race to the bottom with a chronic deterioration of working conditions for Foxconn workers (Chan, Pun and Selden 2015). Indeed, Apple had contributed to making working conditions worse: when Foxconn raised workers's wages following the spate of suicides in 2010, Apple moved part of its production to another supplier, Pegatron, that offered cheaper labour costs. For Chan and Pun, Foxconn is not an exception, but a "microcosm of the lives of Chinese migrant workers" and suicides are an extreme manifestation of what hundreds of millions of workers experience (Chan and Pun 2010, 1).

In China, the outsourcing of electronics manufacturing was facilitated by the Chinese state, which put in place pro-market liberalising policies designed to attract foreign investment. Since 1978, when Deng Xiaoping introduced a programme of 'market socialism' reforms, there has been a massive decrease in employment from agriculture, fishing and mining and an increase in manufacturing and low-skill service jobs (Fuchs 2014). In its ambition to transform China into the "factory of the world", the state implemented policies of proletarianisation which forced rural migrant workers into the cities, thereby creating "a new millions-strong working class" (Pun, Chan and Chan 2010, 132). Once in the cities, rural migrants are denied the rights and status of urban residents and find themselves locked into minimum wage jobs with few benefits or rights (Chan and Pun 2010). Whilst China's model of corporate domination with the support of the state has generated high-speed economic growth and a digital revolution, it has also deepened labour and social inequalities.

At Foxconn, 18 young migrant workers between the ages of 17 and 25 attempted suicide by jumping from the roofs of the production-cum-dormitory sites where they worked in Shenzhen, resulting in 14 deaths (Chan and Pun 2010). The victims worked on the assembly line, experiencing working conditions that are typical of material labour in today's outsourced supply chains: long hours, unpaid work, overcrowded dormitories and military-style management. Many are deprived of decent wages and benefits, have little social protection and are denied access to trade unions to make their voices heard. For many years, labour rights groups have investigated, documented and publicised conditions in China's supplier factories. For instance, in 2008, China Labour Watch undertook an investigation of factory 
conditions at Foxconn that resulted in a report "Follow Up on Foxconn" which revealed serious labour violations, including unpaid wages, compulsory overtime and overcrowded dormitory conditions (CLW 2008). The report describes a disciplinarian regime where workers are obliged to finish the rice eaten in factory canteens or risk paying a fine, and where they sleep in unsanitary and overcrowded dormitories. Most workers were forced to stand while working 12 hour shifts and were only permitted to take one day off per month during peak production times. The report includes the personal testimony of a 19-year-old male worker who left his home in rural China to work at Foxconn's production site in Shenzhen. He describes the dehumanising conditions that characterise factory life: "A supervisor told us that working at Foxconn requires total obedience; you do not need to be intelligent or highly skilled. After a week of training, we concluded that at Foxconn, we shouldn't treat ourselves as human beings, we are just machines". (Ibid., 4). Following widespread media reports on the Foxconn suicides, SACOM researchers undertook a detailed investigation of conditions in Foxconn's production facilities including interviews with workers and undercover investigations by researchers posing as workers. This culminated in a detailed report published in October 2010 which described the experiences of workers in Foxconn's production sites ("Workers as Machines. Military Management in Foxconn"). The report revealed practices including enforced overtime and bullying by management. They described a "military-style management" that "boosts productivity through the degradation of workers into dehumanized machines" (SACOM 2010, 2). Some workers reported being publicly humiliated or subjected to violence by security guards. According to this report, two of the suicides at Foxconn were triggered by punishments meted out on the suicide victims by managers. Since 2010, the threat of mass suicide has also been used by workers at Foxconn as an instrument with which to appeal for improved working conditions. Hence on 2 January 2012, about 300 workers allegedly took to the roof of Foxconn and threatened to kill themselves by jumping off unless they were given a wage raise (Rundle 2012).

The Foxconn suicides were the outcome of intense workplace pressures and, in particular, the demands of just-in-time production that transfers economic pressures onto frontline workers, pushing them to the brink of physical and mental endurance. If the suicides reveal the extreme physical hardships of material labour, they also reflect the psychological trauma experienced by the displaced lives who make up the company's workforce. 85 percent of the company's workforce are young people from rural areas and many have recently moved into the cities where they are cut off from their families and from their former lives (Chan and Pun 2010). On the assembly line, they spend long days of "enforced silence", as conversation between workers is prohibited and it is impossible to form friendships (Chan 2013, 4). Within the dormitories, room-mates often alternate between those on day and night shifts and the effects of sheer exhaustion, together with cultural and linguistic differences, make social interaction difficult. One suicide survivor who was crippled when attempting to take her own life described experiences of profound loneliness and social isolation at Foxconn, referring to the factory as "a massive place of strangers" (Ibid., 4). Chan (2015) undertook undercover research in Foxconn's dormitories, going in to speak to female workers and investigate their living conditions. She describes young, isolated and vulnerable women who often lack the experience needed to express and channel their grievances. Workplace conditions can therefore be internalised and manifest themselves in the form of physical pain, with women complaining of stomach pain or other ailments. For Chan, the dormitories are not a 
place to live or socialise but simply a site in which to renew labour power (Ibid.). As trade unions are controlled by management, workers do not have the means to communicate their grievances, protect their rights or engage in collective bargaining. In the case of Foxconn, suicides manifest the extreme physical and psychological suffering that characterises outsourced material labour within today's digital economy.

\section{Why Suicides Threaten}

Critics have shown how the digital economy is underpinned by an "ideological technological fetishism" that idealises and mythologises digital commodities whilst concealing the labour processes that bring these products to us. Gadgets such as the mobile phone have an immediacy, simplicity and high speed that hides complex and globally-dispersed labour processes and "recodes the actuality of blood and sweat into play, desire, good looks, appealing design and lifestyle ideologies" (Fuchs 2014, 287). For Mosco (2004), the rise of communication technologies is sustained by the "digital sublime", a collective belief that technology and cyberspace is opening up an exciting new world that transcends space and time. Maxwell and Millar refer to "a technological sublime" that is imbued with utopian possibilities and that occludes the dirty work that brings shiny gadgets to us (2007). Yet the occlusion of labour is not simply a consequence of a commodity fetishism inherent within capitalism that naturalises products and presents social relationships as things. It is also an outcome of the deliberate intervention of political and business elites who have sought to keep human labour hidden from public view. In France Télécom, the extreme psychological suffering of workers was masked behind an outward appearance of 'soft' cognitive labour and extensive formal workplace rights. Furthermore, workers' suffering could not be easily articulated within a traditional language of trade union militancy (Waters 2014). Yet the excellent conditions of work, and its cognitive nature, did not protect employees from management tactics based on psychological bullying that pushed them to the brink. In China, Foxconn's world of physical labour is kept scrupulously hidden by business elites whose economic profits depend precisely on eclipsing the actual conditions of production. Apple and other corporations are marked by a highly "secretive culture" that until recently kept hidden the names and locations of supplier factories in China (Chan 2012 , 2). Workplace suicides can be seen to pose a threat to this power equilibrium because they subvert economic relationships that reduce human labour to an abstraction and instead give it material embodiment in the form of extreme corporeal suffering. Suicides transgress economic, symbolic and ideological laws that seek to negate all signs of physical and mental labour, and are a visceral reminder of the embodied pain involved in bringing products and services to us.

On the one hand, suicides and their social recognition jeopardise the power and legitimacy of business elites whose profits depend on constructing a positive corporate reputation and brand image. For instance, in the case of Apple, the success of the iPhone is linked to "emotional branding" that presents this product as a cool, slick and care-free commodity: "Now more than ever, Apple depends on the strength of its brand power to eclipse the mistreatment and exploitation of workers in its supply chain" (Cole 2013, 2, 5). Apple has constructed a corporate reputation as a socially responsible and ethical company that cares deeply about its workers and their rights. Its promotional campaigns present the company as a force for good in the world, seeking to advance human rights and improve the working conditions of employees across the globe. It is for this reason that Apple and other corporations 
seek to keep their dependence on mass physical labour well hidden. Within supplier factories, workers are subject to strict surveillance, routinely searched and prohibited from talking to journalists. Factories are entirely walled, with security guards positioned at each entrance, and workers enter the factory by swiping an electronic staff card (Pun et al. 2016). These conditions prompted the Wall Street Journal to describe Foxconn's Shenzhen plant as the "forbidden city of Terry Guo" (Xu and Li 2013). It was only as a result of the intense pressure placed on Apple in the aftermath of the 2010 suicide crisis that corporate executives agreed to disclose details of its supplier factories in China, information that no other major electronics corporation provides. The suicide crisis made dramatically visible the realities of material production that lay behind Apple's branding power and meant that the pristine image of the iPhone was tainted by visceral images of blood, flesh and violence. In the aftermath of the suicide crisis, Apple went to considerable lengths to rehabilitate its reputation and reconfigure the image of the Chinese worker that was portrayed during the suicide crisis. In its annual Supplier Responsibility reports, alongside pledges to improve social and working rights, it presents images of smiling Chinese workers who appear happy, contented and fulfilled as they assemble gadgets for Apple.

Similarly, France Télécom, as a former state-owned utility, has associated itself with public sector ideals of egalitarianism, universalism and social fairness that are seen to define the French nation itself. With its historical origins in the creation of the first Ministry for Posts and Telegraphs, France Télécom has identified itself with a universal mission to provide fair and equitable telecommunications for all citizens, irrespective of social or geographical differences. Even the company's privatisation initiated in 1997 was driven by state-led nationalist concerns for reasserting French economic interests on the international stage. The company's employees, imbued with a public service ethos, were proud of the technological prowess of the company and its capacity to lead major innovations, such as the introduction of Minitel over a decade before the Internet became widely available. France Télécom's privatisation was marked not only by a transformation of its sources of finance, with a shift from the state to financial markets, but also by a profound transformation in the ethos and values underpinning the company. Management endeavoured to substitute the company's public service ethos with a logic based on profit, shareholder value and "pure finance" (Diehl and Doublet 2010, 67). As the company's public service employees were allowed to retain their rights and status, France Télécom could claim to be privatising the company whilst protecting its employees. The suicide crisis revealed the disjuncture between claims to respect public sector rights and the brutal management tactics that were in reality directed against employees.

On the other hand, workplace suicides call into question the role of governments which have colluded with business in defining conditions within the restructured workplaces in which suicides take place. Suicides can be seen to reflect the rise, under neoliberal globalisation, of "a politically transformed state" whose role is no longer to protect social rights in the face of market forces, but to act as the "defender of global corporate interests" (Webster, Lambert and Bezuidenhout 2008, 25). Governments reinforce the power and freedom of private interests, facilitating the rise of multinational corporations with unparalleled economic power and territorial reach. At the same time, they restrict labour rights in terms of wages, social benefits, contractual rights and collective bargaining. The shift to economic liberalisation was legitimised in the public sphere by appealing to the general interest, and by reference to universal social benefits such as increased jobs, investment, 
competitiveness and growth. In their political speeches, leaders invoked "the globalisation myth" and promised that the short-term pain of economic restructuring would lead to long-term social rewards for all (Danford, Richardson and Upchurch $2003,7)$. The reality of today's globalised workplaces, in which individuals are placed under such intense economic pressures that some choose to take their own lives, interferes with such positivistic rhetoric about the public good. It places the economic choices of governments under scrutiny and raises questions about the social and moral ends of state-driven economic liberalisation.

In France, the state played an influential role in defining the economic conditions in which France Télécom privatised. The company was intended by the government to be a beacon of successful privatisation, "un laboratoire du privé", that would showcase the methods that could be used elsewhere in France's public sector (Du Roy 2009). Whilst the impetus for privatisation came from Europe, it was the French state that defined through successive legislation the terms in which privatisation took place. Hence the 1990 Quillès law transformed the company into a "public establishment" and the 1996 Fillon law transformed it into a "société anonyme", a limited company, and approved an opening of its capital on financial markets. The process of privatisation was completed in 2004 by removing the state's prerogative as majority shareholder and opening up all its capital. Privatisation was initially hailed as a resounding success, and with the first sale of shares, 12 billion Euros were transferred into the state's coffers. Yet, following privatisation and CEO Michel Bon's frenzied acquisition of overseas telecom companies, the government was forced to recapitalise the company to the tune of 15 billion Euros of public funds (Diehl and Doublet 2010).

According to critics, the French state knew about the devastating effects on the workforce of the company's management policies, but chose to do nothing about it. The government assumed a voluntary "blindness", preferring to stick its head in the sand rather than confront the reality of the crisis (Du Roy 2009, 175). In 2002, Senator Gérard Larcher presented to Senate a detailed report on France Télécom's privatisation in which he invoked the suffering of the workforce, referring to "a world of work that has been completely disrupted". In his report, he cites a trade union leader who describes a "deterioration of working and living conditions" since privatisation (Larcher 2002). Similarly, Senator Marie-Claude Beaudeau took a close interest in France Télécom and intervened regularly in parliament to signal the changed conditions affecting the company's workforce. In a speech on 3 February 2004, she declared that "workplace suffering has been rising at an alarming scale in recent years (...) Physical and mental exhaustion is increasing, as is despair and depression. Stress is commonplace". (Quoted in Decèze 2008, 239.) At the height of the suicide crisis, the state was still the company's largest shareholder, with $27 \%$ of its shares (in 2009), and government was represented directly in the company's strategic and management decision-making, holding 11 of its 21 seats on the company's executive board. It is noteworthy that the majority of France Télécom bosses come directly from government ministries or join government after their period at France Télécom. For instance, France Télécom's CEO since 2010, Stéphane Richard, who was appointed by government in response to the suicide crisis, ran two ministerial cabinets before joining the company. Thierry Breton left France Télécom to become France's Minister of the Economy in 2005. In 2007, at a time when suicides were beginning to rise, Didier Lombard was awarded the Légion d'honneur, France's highest decoration, by the French State (Breton and Richard have also been awarded this accolade). Far from being an innocent bystander to 
economic events beyond its control, the state was directly implicated in defining the workplace conditions in which the suicides took place. For Renou $(2009,1)$, the suicides should not be treated as an epidemic that has pathological causes, but as the outcome of political decisions "orchestrated deliberately and knowingly from the top to the bottom of the company hierarchy".

As critics have shown, the rise of China as a major economic power was not a natural consequence of market liberalisation, but was state-initiated and achieved in collusion with transnational capital in search of cheap labour. Foxconn, like other multinationals, was supported by central and local governments anxious to pander to their economic needs by providing infrastructural support, cheap land, tax exemptions and preferential policies: "The astonishing speed of capital expansion across geographical space was achieved through an alliance with the Chinese state" (Pun and Chan 2012, 385). Local governments currently compete to have Foxconn set up a new factory in their area and routinely ignore violations in labour regulations (Pun et al. 2016). In some regions, local governments recruited young people in towns and villages to work for Foxconn, thereby lowering corporate recruitment costs. Once in the cities, rural migrants were categorised as "temporary residents" and were therefore excluded from the social protections in relation to employment, welfare and housing which were available to urban workers. Hence, state and corporate interests colluded in undermining the labour rights of Foxconn's workers.

Yet the way in which state authorities responded to the suicide crises in France and China differed markedly, reflecting broader differences in state systems, levels of social protection and trade union representation. In France, the suicide crisis was forced into the open when the trade union SUD PTT took legal action against France Télécom in September 2009, accusing management of brutal management tactics and invoking a 2002 law which prohibits "moral harassment" that harms the physical or psychological health of employees. This prompted Paris prosecutors to open a criminal investigation against six France Télécom executives, which has become the focus of widespread media attention both nationally and internationally. French politicians have been obliged to intervene directly on the question of the France Télécom suicides, addressing the media publicly and engaging in parliamentary discussions on working conditions at the company. Despite efforts by business and political elites to prevent the crisis coming into the open, the suicide crisis became the focus of intense scrutiny and controversy in public and political life.

In China, by contrast, where the state exerts authoritarian influence, where trade unions are controlled by management and where workplace suicide is not officially recognised in law, the authorities responded in a far less transparent and open way. Hence, the state responded by sending high-level officials from the All China Federation of Trade Unions, the Ministry of Human Resources and Labor Protection and the Ministry of Public Security into Foxconn. The priority was to contain the crisis and prevent an escalation of media interest by shutting down independent media sources. This meant that, unlike France Télécom, Foxconn was under less political pressure to change course and alter its workplace practices.

\section{States of denial}

For Cohen $(2001,10)$, "states of denial" prevail when individuals and societies are presented with information that is too disturbing, threatening or unsettling to be fully absorbed or openly acknowledged. For the individual, such reactions may be unconscious, spontaneous or natural, and constitute a coping mechanism that stems from an inability to live with uncomfortable truths. Yet, as Cohen indicates, states of 
denial may also be orchestrated, organised or sustained in order to defend the vested interests of powerful groups: "At the other extreme are forms of denial which are public, collective and highly organized. In particular, there are denials that are initiated, structured and sustained by the massive resources of the modern state" (Ibid.). Suicides at Foxconn and France Télécom were subject to modes of repression that were intended to conceal the suicides, prevent their social recognition and obfuscate their connections to the workplace. These tactics were deliberately used by political and economic elites in order to defend their vested interests and conceal the realities of production.

\subsection{Normalisation}

A common form of denial consists of normalisation, in which discursive techniques are used to minimise an event or make it appear normal or routine (Cohen, 2001). Examining historical cases of genocide, Cohen argues that this is achieved by questioning the statistics available, so that "the number of dead victims is smaller than usually stated" (Ibid., 133). At both Foxconn and France Télécom, elites invoked suicide statistics in order to challenge the significance of workplace suicides and present them as unremarkable, normal or routine. In the face of growing media criticism, Foxconn's public communications director commented to the press, "Given its size, the rate of self-killing at Foxconn is not necessarily far from China's relatively high average" (quoted in Chan 2013, 1). Meanwhile, Apple's Steve Jobs claimed that the suicide rates among Foxconn employees were below that of US corporate employees (Xu and Li 2013). Similarly, when French political leaders intervened in the France Télécom suicides after a long period of silence, it was to minimise their significance. The then-Minister of Employment, Xavier Darcos, commented that suicide cases at France Télécom were unexceptional by national standards. In another statement, he trivialised the working conditions that drove individuals to suicide and remarked "there is something worse than stress in work and it is stress when out of work" (quoted in Diehl and Doublet 2010, 92). Yet critics in both cases have countered these arguments by highlighting the exceptional demographic characteristics of the suicidal individuals involved. At Foxconn, those who jumped to their deaths were in the prime of youth (aged between 17 and 25) and worked for a single company, in a single industrial district (Chan 2013). At France Télécom, the preponderantly male technicians and engineers who committed suicide were highly educated and skilled, making them exceptional in national statistical terms (Baudelot and Gollac 2015).

One means of normalising a crisis situation is through evasive tactics and a refusal to acknowledge or confront the suicides taking place. At France Télécom, company bosses ignored repeated warnings from medical experts about the devastating effects of the company's restructuring policies on employees' mental health. When privatisation was initiated in 1997, occupational health doctors began to raise the alarm about rising stress levels, and investigations into workplace stress were carried out at France Télécom sites in Paris, Lyon, Marseille, Grenoble, PoitouCharentes, Normandy, La Rochelle and Voiron. Yet faced with mounting evidence from a range of occupational specialists, management "went into denial" (Du Roy 2009, 176). Similarly, even after the eighth jump at Foxconn on 11 May 2010, Foxconn executives continued to insist that their treatment of workers was "world class" (Chan and Pun 2010, 10). When company boss Terry Gou finally broke his silence over the ten worker suicides, it was to deny that he was running "blood and sweat factories" (Ibid.). Meanwhile, Apple responded by defending working 
conditions and boasting about the facilities available to workers. Hence, Apple boss Steve Jobs, speaking at the All Things Digital conference in California, defended conditions at Foxconn and declared that "Foxconn is not a sweatshop" (BBC News, 2010). Overlooking the widespread violations of labour law, he emphasised the state-of-the-art facilities in Foxconn's Shenzhen production site: "You go in this place and it's a factory but, my gosh, they've got restaurants and movie theatres and hospitals and swimming pools. For a factory, it's pretty nice". (Ibid.)

A key strategy used by Apple to re-establish its reputation in the face of the intense public relations crisis was to launch its own investigations into working conditions at supplier factories and to publicise claims about the improvements it has made. In February 2011, Apple released its Supplier Responsibility Progress Report to show the remedial measures taken by Foxconn in the aftermath of the suicides, praising the swift emergency responses of the company. Shifting responsibility for the suicides to Foxconn, Apple failed to mention its own responsibility in placing workers under extreme pressure to meet production deadlines (Pun et al. 2016). Similarly, the 2012 audit of Foxconn commissioned from the Fair Labor Association (FLA) of which Apple is a corporate member has attracted widespread criticism from researchers and labour rights activists. The FLA report highlighted the same violations that labour rights activists had been reporting on for years and that Apple had persistently ignored. Apple's response to the FLA report did little to alter the structural conditions of production and the exploitative practices which contribute to the company's substantial profits. For Nova (2012), these monitoring measures are a public relations exercise that provide an inexpensive means for Apple to manage the threat to its reputation whilst maintaining its highly lucrative labour practices. Indeed, corporate-funded monitoring has allowed Apple "to create the impression of legitimate efforts to protect workers, without having to incur the substantial costs, in terms of labor flexibility as well as dollars, of making broad improvements in wages and conditions for the workers who make their products" (Ibid., 3). More recently, Apple has recruited an academic advisory board composed of leading US academics in order to conduct research into conditions in its supply chain. Whilst refusing to collaborate with other labour rights researchers in SACOM, the new advisory board allows Apple to appeal to independent scientific authority in its claims about labour rights. When the BBC aired a documentary called "Apple's Broken Promises", which claimed that the corporation was continuing to violate labour rights in the aftermath of the suicide crisis, the head of the academic advisory group, Professor Richard Locke, was quick to defend Apple's reputation, claiming to be "extremely impressed" by Apple's efforts on labour issues (Wakabayashi 2014).

\subsection{Rationalising self-killing}

Another form of denial consists of rationalising suicides by attributing them to higher or inescapable forces beyond human influence: "Another move is to attribute responsibility to forces - named or unknown - that supposedly have nothing to do with the government and are beyond its control" (Cohen 2001, 109). At Foxconn and France Télécom, elites attempted to justify the suicides, or at least the labour conditions that gave rise to them, by appealing to higher economic imperatives such as global competition, liberalisation or restructuring. Such discourse prioritised the company's survival in the face of global competition and treated suicides as a form of collateral damage in a necessary economic war. In China, workplace suicides were the outcome of a situation of economic expediency in which multinational corporations such as Apple derive vast profits from an exploitation of underpaid and 
illegal Chinese labour. Suicides were rationalised to the extent that they reflect normalised and widely used economic practices that are deployed in order to maximise profit margins.

At France Télécom, a hardened management refused to reconsider its economic strategy despite the rise of suicides by employees and growing evidence of chronic workplace stress. It was only as a result of a direct intervention by the French government that Didier Lombard took the decision to suspend temporarily the policy of forced redeployment, and this was shelved when Stéphane Richard took over as company CEO in 2010. Even when he was placed under judicial investigation, Lombard continued to defend his policies in the name of economic necessity: "I forcefully reject the idea that (restructuring) plans vital to the survival of the company might have been the cause of these human tragedies" (Le Monde 2012). Such rhetoric has the effect of rationalising extreme suffering in the interests of higher economic needs.

\subsection{Individualisation}

A common discursive strategy is to individualise suicides and frame them as isolated, sporadic and personal events linked to the emotional or mental flaws of the individual. At France Télécom, Louis-Pierre Wenes, the company's deputy director, described the suicides as individual situations that were linked to considerable personal difficulties (Du Roy 2009). Following the suicide of a 32-year-old female employee who threw herself out of the office building where she worked in western Paris on 11 September 2009, representing the twenty-third suicide at the company, CEO Didier Lombard referred callously to a "contagion effect" and "a suicide trend" ("une mode de suicide") at the company, a remark that led to his subsequent dismissal (quoted in Waters, 2014). Meanwhile Claude Guéant, secretary general of the Elysée, defended company bosses against mounting criticism declaring to the press, "you cannot reduce 23 employee suicides to a problem of work organisation" (quoted in Rabatel 2011, 5). Although company bosses finally agreed to meet trade unions on 18 September 2009, they continued to deny that suicides were workrelated, refuting "any connections to management" and treating the suicides as "individual dramas, connected to personal problems" (Ibid., 5).

In China, Foxconn hired psychologists and psychiatrists to defend it in the wake of the suicides. Bosses constructed a narrative according to which the record number of suicides was not related to management style, working conditions or wage policies but reflected the personal problems of the workers and concerned issues such as poor mental health, depression, distress over having debts or family problems (Pun et al. 2014). After the fifth suicide, Foxconn's management suggested that the woman in question was experiencing relationship issues with her boyfriend and that the suicide had nothing to do with work. Similarly, after the sixth suicide, Foxconn's spokesperson Liu Kun suggested that the young workers were psychologically weak compared with the older generation and were unable to cope with societal pressures (Xu and Li 2013). In a victim-blaming approach, the Foxconn CEO's personal assistant Chen Peng remarked that "suicide is foolish, irresponsible and meaningless and should be avoided" (quoted in Chan 2013, 6).

When company bosses at Foxconn and France Télécom were eventually forced to intervene, this was to introduce preventative measures, which tended to medicalise the suicides, treating them as individual psychological problems rather than a collective phenomenon linked to workplace conditions. When suicides were at their peak at Foxconn, the company placed safety nets around the roofs, invited 
monks to the factory to exorcise the spirits of the dead and set up 'care hotline' facilities in all its factories across China. Management left intact the underlying workplace structures and practices that had triggered the suicides, such as intensified production deadlines, illegal overtime work and management brutality (Chan and Pun 2010). In May 2010, the Foxconn Human Resources Director attempted to make workers sign a pledge agreeing to waive their family's right to compensation following a suicide. This consent letter sought not only to limit Foxconn's liability but also to ensure that responsibility for future suicides was placed on the individual worker (Chan 2013). Following criticism from labour rights groups, this initiative was dropped. Similarly, France Télécom bosses reacted by means of individualised support, including a counselling service and an emergency hotline. Yet the company's ongoing restructuring process continued unabated when workplace suicides were at their peak. In fact, a communiqué published by France Télécom's Human Resources department on 26 August 2009 emphasised the urgency of pressing ahead with restructuring, referring to "the necessity for the company to pursue its transformation in a context of rapid evolution and strong competitive pressure" (Du Roy 2009, 31).

\subsection{Repression}

Elites at Foxconn and France Télécom used repressive tactics designed to erase or censor information on workplace suicides and prevent it coming into the public sphere. At France Télécom, company bosses used specific modes of repression in order to prevent enquires into workplace stress from taking place. Hence, in Limousin in 2005 and in Auvergne in 2006, France Télécom went to court to prevent investigations into the health effects of workplace restructuring (Decèze 2008). Following the suicide of a 37-year-old computer technician in Paris on 16 September 2008, France Télécom went to court to block an investigation into workplace stress in the company where he worked. Similarly, following the attempted suicide on 6 January 2009 of a technician who had left a letter complaining of humiliation and harassment by his superiors, France Télécom management sought to hinder an enquiry by an external agency and ordered its staff not to speak to the consultants involved. Occupational health doctors were also placed under pressure and forced in some cases to modify their findings or to remain silent about them. A number of doctors who resigned from France Télécom criticised management for preventing them from working properly and compromising their impartiality (Du Roy 2009). When two occupational health doctors were invited by trade unions to speak at a training event on workplace stress in December 2007, France Télécom management prohibited them from doing so, arguing that they had a duty to respect "confidentiality" and "impartiality" (Ibid., 179).

In China, the state responded to the suicide crisis with a censorship of the media that aimed to contain damage to Foxconn's corporate reputation. On 27 May 2010, a thirteenth Foxconn employee aged 25 attempted suicide by slitting his wrists after failing to jump from the building where he worked. Suicides had been attracting increasing scrutiny from the media both in China and across the international stage. The following day, on 28 May, the Chinese government, at the request of local government officials, imposed a media blackout prohibiting all negative reporting on Foxconn. All news websites were instructed to remove special reports on Foxconn and all web forums were requested to delete related posts: no new posts were allowed to go public (Pun et al. 2014). Student activists linked to the University Research Group who had set up a blog dedicated to Foxconn worker victims and 
their families discovered that their webpage had been blocked (Chan 2015). The press media in China was instructed to publish news from the State's official news agency (Xinhua news) or from Foxconn's own public statements. In its censorship of the media, the Chinese prioritised Foxconn's corporate reputation over the lives and conditions of Chinese workers. Rather than investigating and taking action to protect and improve working conditions, state efforts focused on suppressing negative media reporting of the suicides.

\section{Conclusion}

Workplace suicides lay bare an economic order and an international division of labour that subjects workers to such unbearable pressures that some choose to take their own lives. They expose, beneath the surface of reified economic relations, lived and material experiences of extreme human suffering. The suicide cases examined here took place in a sector that is arguably at the frontier of twenty-first century global capitalism that generates an unprecedented maximisation of profits and that produces digital gadgets which are perceived to be innovative, fashionable and highly desirable. We have seen that the success of the information and communications sector is rooted partly in its power of abstraction and a capacity to conceal and obfuscate its connections with real embodied labour. If products such as the smartphone, tablet or other electronic devices have acquired iconic status, this is because they appear pristine and aesthetic, and the real exploitation of physical and cognitive labour that lies behind them is shut off from the public gaze. At both Foxconn and France Télécom, workers were subject to management techniques based on psychological abuse in order to ensure that high-tech and just-in-time electronic products were made readily available. Sociologists of suicide such as Emile Durkheim remind us that suicide is a socially-determined phenomenon whose causes transcend the individual and are located in society itself. Foxconn and France Télécom are not isolated or exceptional cases, but are symptomatic of generalised labour conditions in the digital economy in which the drive towards economic profits takes precedence over other human considerations. Other companies in the digital economy have also experienced suicides, with six "mysterious deaths" in Huawei in China between 2006 and 2008, and a suicide case at Samsung Korea in 2011 (AsiaNews.it 2010). Further research is needed on workplace suicides across the digital economy in order to establish the causal connections between working conditions and the individual act of suicide.

Suicides are intrusive because they interfere with corporate strategies that tend to fetishise gadgets and conceal material suffering behind their glossy surfaces. Yet we have seen that the stakes in acknowledging and exposing workplace suicides are extremely high. Suicides undermine the slick marketing of the corporate world in which products and services are presented as pure commodities disconnected from any links to human labour. At the same time, suicides call into question the legitimacy of political elites who have colluded with business interests in defining conditions in the new restructured workplaces in which suicides take place. Through policies of economic liberalisation, privatisation and labour market reform, states have prioritised the economic interests of powerful corporations over the basic human needs of individual workers. The reality of violent deaths in today's workplaces calls into question politicians' positivistic rhetoric about the social and public rewards of neoliberal globalisation..

The suicide cases examined here challenge a binary opposition between material and immaterial labour that connects the former with exploitative conditions and the 
latter with emancipatory and progressive forms of work. Despite vast differences in working conditions, social protection and workplace rights, employees at France Télécom and Foxconn shared common experiences of extreme psychological distress. France Télécom employees were not protected by the immaterial nature of their work or their formal workplace rights. The manual and repetitive work of employees on Foxconn's assembly lines did not limit their suffering to physical drudgery alone. Labour rights activists in the case of each corporation succeeded in countering 'states of denial' that sought to trivialise, individualise or disavow the suicides taking place. Through sustained political struggle, they succeeded in breaking forms of censorship, forcing suicides into the open and giving them widespread social recognition. Yet even where political mobilisation has succeeded in countering forms of official denial, a more complex, deeply-rooted and intangible form of denial may persist. For instance, although Apple's reputation was severely tarnished by the suicide crisis, it made record profits through the sale of 169 million iPhones in 2015, making it the most profitable company in the world (Cole and Chan 2015). Similarly, despite the reputational damage inflicted on France Télécom through the suicide crisis, this has not affected its share value on the stock exchange. The company is still classified on financial listings as an ethical company that provides a model of social responsibility (Marcelo 2011). The untrammeled economic success of each company seems to counter the idea that their communication strategies and denial tactics failed in the wake of the suicide crises (Xu and Li 2013). How can record-breaking corporate profits be reconciled with the systemic and widespread human misery and exploitation that produces them? Are Western consumers and investors unaware of the conditions of production that generate suicide, or are they practicing a form of dissonance and a "blocking out" of information because it is simply too harrowing to bear? (Cohen 2001, 4). Whatever answer holds true, it seems that abstract economics and the commercial relationships on which it relies often remain indifferent to the severe human and social suffering that it can generate.

\section{References}

Agrawal, Amit. 2014. Farmers' Suicides in the Vidarbha region of Maharashtra, India: A Qualitative Exploration of their Causes. Journal of Injury and Violence Research 6 (1).

Alemanno, Sylvie, P. and Bertrand Cabedoche. 2011. Suicide as the Ultimate Response to the Effects of Globalisation? France Télécom, Psychosocial Risks and Communicational Implementation of the Global Workplace. Intercultural Communication Studies XX: 2, 2440.

AsiaNews.it. 2010. "Suicide among young Chinese workers". Accessed 5 March 2016. http://www.asianews.it/news-en/Suicide-among-young-Chinese-workers--18305.html

Australian Medical Association. 2014. Urgent Action Needed on Workplace Suicide. Accessed 19 March 2016. https://ama.com.au/ausmed/urgent-action-needed-workplacesuicide

Baudelot, Christian and Michel Gollac. 2015. Que peuvent dire les suicides au travail? Sociologie 2 (6): 195-206.

Benach, Joan, Alejandra Vives, Marcelo Amable, Christophe Vanroelen, Gemma Tarafa, and Carles Muntaner. 2014. Precarious Employment: Understanding an Emerging Social Determinant of Health. Annual Review or Public Health 35: 229-53. http://www.annualreviews.org/doi/full/10.1146/annurev-publhealth-032013-182500

Berardi, Franco. 2015. Heroes: Mass Murder and Suicide. London: Verso Books.

BBC News. 2010. 'Apple boss defends conditions at iPhone factory'. Accessed 2 June 2016. http://www.bbc.co.uk/news/10212604 
Brouillette, Sarah. 2009. Creative Labor. Mediations 24 (2): 140-149. Accessed 1 June 2016. http://www.mediationsjournal.org/articles/creative-labor

Burgi, Noëlle, Monique Crinon and Sonia Fayman. 2008. De l'art de programmer la maltraitance au travail. Unpublished report by the Observatoire du stress et des mobilités forcées.

Cazi, Emeline. 2014. "France Télécom, la mécanique de la chaise vide”. Le Monde, 12 December. Accessed 1 March 2015. http://www.lemonde.fr/societe/article/2014/12/12/france-telecom-la-mecanique-de-lachaise-vide 4539636 3224.html

Chan, Jenny. 2012. "Biting the Rotten Apple: Taking on Foxconn". Red Pepper, August. Accessed 1 May 2014. http://www.redpepper.org.uk/biting-the-rotten-apple/.

Chan, Jenny. 2013. A Suicide Survivor: The Life of a Chinese Worker. New Technology, Work and Employment 28 (2): 84-99.

Chan, Jenny. 2015. Interview by Sarah Waters. Skype interview. 17 July.

Chan, Jenny and Ngai Pun. 2010. Suicide as Protest for the New Generation of Chinese Migrant Workers: Foxconn, Global Capital, and the State. The Asia-Pacific Journal 18 (37, 2). http://apijf.org/-Jenny-Chan/3408/article.html

Chan, Jenny, Ngai Pun and Mark Selden. 2015. Apple's iPad City: Subcontracting Exploitation to China. In Handbook of the International Political Economy of Production, edited by Kees van der Pijl, 76-97. Cheltenham: Edward Elgar.

Chen, Hsin-Hsing. 2014. A la limite du monde materiel. Deux cas de reconnaissance légale à Taïwan. Travailler 31: 89-117.

China Labor Watch. 2008. Follow Up on Foxconn. Accessed 6 March 2015. http://www.chinalaborwatch.org/report/26

Cohen, Stanley. 2001. States of Denial: Knowing about Atrocities and Suffering. Cambridge: Polity.

Cole, Lisa. 2013. "Whimsical Branding Obscures Apple's Troubled Supply Chain”. The Society Pages, 14 August. Accessed 1 June 2015. http://thesocietypages.org/socimages/2013/08/14/whimsical-branding-obscures-applestroubled-supply-chain/

Cole, Lisa and Jenny Chan. 2015. "Despite Claims of Progress, Labor and Environmental Violations Continue to Plague Apple". Truthout, 19 February.

Danford, Andy, Mike Richardson and Martin Upchurch. 2003. New Unions, New Workplaces: A Study of Union Resilience in the Restructured Workplace. London: Routledge.

Decèze, Dominique. 2008. La Machine à broyer. De France Télécom à Orange: quand les privatisations tuent. Paris: Gawsewitch.

Dejours, Christophe. 1998. Souffrance en France: La banalisation de l'injustice sociale. Paris: Editions du Seuil.

Dejours, Christophe. 2014. Interview by Sarah Waters in person. 4 November.

Dejours, Christophe. 2015. Le Choix: Souffrir au travail n'est pas une fatalité. Paris: Bayard éditions.

Dejours, Christophe and Florence Bègue. 2009. Suicide et Travail: Que Faire? Paris: Presses Universitaires de France.

Diehl, Bruno and Gérard Doublet. 2010. Orange: le déchirement. France Télécom ou la dérive du management. Paris: Gallimard.

Durkheim, Emile. 1930 [1897]. Le Suicide. Paris: Félix Alcan.

Du Roy, Ivan. 2009. Orange stressé: le management par le stress à France Télécom. Paris: La Découverte.

Dyer-Witheford, Nick. 2014. The Global Worker and the Digital Front. In Critique, Social Media and the Information Society, edited by Christian Fuchs and Marisol Sandoval, 165178. New York: Routledge.

Fuchs, Christian. 2014. Digital Labour and Karl Marx. New York: Routledge. 
Giroux Henry and Brad Evans. 2015. Disposable Futures: The Seduction of Violence in the Age of Spectacle. San Francisco: City Lights Publishers.

Hesseldahl, Arik. 2006. Apple Answers "Sweatshop" Claims. Bloomberg Businessweek, August 20. Accessed 1 July 2016. http://www.bloomberg.com/news/articles/2006-0820/apple-answers-sweatshop-claims

Halbwachs, Maurice. 1978 [1930]. The Causes of Suicide. London: Routledge \& Kegan Paul.

Kawanishi, Yuko. 2008. On Karo-Jisatu (Suicide by Overwork): Why do Japanese Workers Work Themselves to Death? International Journal of Mental Health 37(1): 61-74. Accessed 7 June 2016. https://www.jstor.org/stable/41345245?seq=1\#page scan tab contents

Lacaze, Stéphanie. 2001. “Immolation d'un salarié. France Télécom accusée”. Libération, 16 December. http://www.liberation.fr/futurs/2011/12/16/immolation-d-un-salarie-francetelecom-accusee 782291

Larcher, Gérard. 2002. Rapport no.274. Le bilan de la loi no. 96-660 relative à l'entreprise nationale France-Télécom, 26 March.

Lazzarato, Maurizio. 1996. Immaterial Labour. In Radical Thought in Italy, edited by Paulo Virno and Michael Hardt. Minneapolis: University of Minnesota Press.

Le Monde. 2012. "Suicides à France Télécom: l'entreprise mise en examen pour harcèlement moral", 4 July. Accessed 1 February 2013. http://www.lemonde.fr/economie/article/2012/07/04/suicides-a-france-telecom-didier-

Marcelo, Coralie. 2011. Suicides à France Télécom Réseau Financement Alternatif. Accessed 1 April 2016.

http://agency/images/PDF/ConstituentsASPI/Francais/aspi 060904 presse fr final.pdf

Marlowe, Lara. 2016. "France Télécom accused of driving employees to suicide". The Irish Times, 7 July.

Maxwell, Richard and Toby Millar. 2012. Greening the Media. Oxford: Oxford University Press.

McKercher, Catherine and Vincent Mosco, editors. 2007. Knowledge Workers in the Information Society. Lanham MD: Lexington Books.

Mosco, Vincent. 2004. The Digital Sublime. Cambridge: MIT Press.

Moulier-Boutang, Yann. 2011. Cognitive Capitalism. Translated by Ed Emery. London: Polity.

North, Scott. 2014. Japanese Workers Fight Against Karoshi, Death from Overwork. Red Pepper, September 16. Accessed 1 June 2016.

http://www.redpepper.org.uk/japanese-workers-fight-against-karoshi-death-from-overwork/

Nova, Scott. 2012. "Apple, Reputational Risk, and the Prospects for Labor Rights Reform". Summary of Comments at the Economic Policy Institute on 11 April. Workers Rights Consortium.

Pun, Ngai and Jenny Chan. 2012. Global Capital, the State, and Chinese Workers: The Foxconn Experience. Modern China 38 (4): 383-410.

Pun, Ngai, Chris King-Chi Chan and Jenny Chan. 2010. The Role of the State, Labour Policy and Migrant Workers' Struggles in Globalized China. Global Labour Journal 1 (1): 132-15. Accessed 1 June 2016. http://sacom.hk/wpcontent/uploads/2013/07/2010GlobalLaborJournal-PN.CC.JC .pdf

Pun Ngai, Shen Yuan, Guo Yuhua, Lu Huilin, Jenny Chan and Mark Selden. 2014. Workerintellectual unity: Trans-border sociological intervention in Foxconn. Current Sociology Monograph 62 (2): 209-222.

Pun Ngai, Shen Yuan, Guo Yuhua, Lu Huilin, Jenny Chan and Mark Selden. 2016. Apple, Foxconn, and Chinese Workers' Struggles from a Global Labor Perspective. Inter-Asia Cultural Studies 17 (2): 166-185. Accessed on 30 November 2016.

http://www.tandfonline.com/doi/pdf/10.1080/14649373.2016.1170961 
Qiu, Jack Linchuan. 2016. Goodbye iSlave. A Manifesto for Digital Abolition. UrbanaChampaign: University of Illinois Press.

Qiu, Jack Linchuan, Melissa Gregg and Kate Crawford. 2014. Circuits of Labour: A Labour Theory of the iPhone Era. triple C: Capitalism, Communication \& Critique 12(2): 564-581. Accessed on 20 January 2017. http://www.triplec.at/index.php/tripleC/article/view/540/607

Rabatel, Alain. 2011. La Levée progressive du tabou des responsabilités socioprofessionnelles dans les suicides en lien avec le travail à France Télécom (fin aoûtoctobre 2009. Questions de Communication 20: 1-27. Accessed 1 June 2014. http://questionsdecommunication.revues.org/2045

Renou, Gildas. 2009. Les laboratoires de l'antipathie. A propos des suicides à France Télécom Journal du Mauss, 29 September. Accessed 11 May 2010. http://www.journaldumauss.net/./?Les-laboratoires-de-l-antipathie-A

Reeves, Aaron, Martin McKee and David Stuckler. 2014. Economic Suicides in the Great Recession in Europe and North America. The British Journal of Psychiatry 205: 246-247. Accessed 1 February 2015. http://bip.rcpsych.org/content/205/3/246

Routley, Virginia and Joan Ozanne-Smith. 2012. Work-related suicide in Victoria, Australia: A broad perspective. International Journal of Injury Control and Safety Promotion 19 (2): 131-134.

Rundle, Michael. 2012. "300 Chinese Foxconn workers 'threaten mass suicide' at Xbox Plant, reports claim". Huffington Post, 10 January.

SACOM. 2010. "Workers as Machines: Military Management in Foxconn”, October 13. Accessed 15 May 2011. http://www.sacom.hk/?p=740

Sandoval, Marisol. 2013. Foxconned Labour as the Dark Side of the Information Age: Working Conditions at Apple's Contract Manufacturers in China. triple C: Communication, Capitalism \& Critique 11(2): 318-347. Accessed 15 November 2016. http://triplec.at/index.php/tripleC/article/view/481

Sassen, Saskia. 2014. Expulsions. Brutality and Complexity in the Global Economy. Cambridge, MA: Harvard University Press.

Sergent, Denis. 2009. Les Suicides au travail ne diminuent pas. La Croix, 29 July.

Stuckler, David and Sanjay Basu. 2013. The Body Economic: Why Austerity Kills. Philadelphia: Basic Books.

Technologia. 2010. Etat des lieux sur le stress et les conditions de travail: Introduction et synthèse du rapport principal. Paris: Technologia.

Tiesman, Hope, M., Srinivas Konda, Dan Hartley, Cammie Chaumont Menéndez, Marilyn Ridenour, and Scott Hendricks. 2015. Suicide in US Workplaces, 2003-2010: A Comparison with Non-Workplace Suicides. American Journal of Preventative Medicine 48(6): 6 74-682. Accessed 6 October 2016. https://www.ncbi.nlm.nih.gov/pmc/articles/PMC4530968/

Terranova, Tiziana. 2000. Free Labor: Producing Culture for the Digital Economy. Social Text 18 (2): 33-58.

http://www.electronicbookreview.com/thread/technocapitalism/voluntary

Wakabayashi, Daisuke. 2014. "BBC says Apple suppliers continue to violate labor standards". Wall Street Journal, 19 December.

Waters, Sarah. 2014. "Capitalism's Victims: Increasingly dehumanizing work has caused an epidemic of suicides in France". Jacobin, 13 November.

Waters, Sarah. 2015. Suicide as Protest in the French Workplace. Modern \& Contemporary France 23 (4): 491-510.

Waters, Sarah. 2016. Suicide Voices. Testimonies of Trauma in the French Workplace. Medical Humanities. Accessed 2 February 2017. http://mh.bmj.com/content/early/2016/09/09/medhum-2016-011013

Waters, Sarah and Chan, Jenny. 2016. "How work can lead to suicide in a globalised economy". The Conversation, 16 August. Accessed 1 September 2016. 
https://theconversation.com/how-work-can-lead-to-suicide-in-a-globalised-economy$\underline{62847}$

Webster, Edward, Rob Lambert and Andries Bezuidenhout. 2008. Grounding Globalization: Labour in the Age of Insecurity. Oxford: Blackwell Publishing.

$\mathrm{Xu}$, Kaibin and Wenqing Li. 2013. An Ethical Stakeholder Approach to Crisis

Communication: A Case-Study of Foxconn's 2010 Suicide Crisis. Journal of Business Ethics 117 (2): 371-386. Accessed 15 December 2016. http://link.springer.com/article/10.1007/s10551-012-1522-0

Zhao, Yuezhi and Robert Duffy. 2008. Short-Circuited? The Communication and Labor in China. In Knowledge Workers in the Information Society, edited by Catherine McKercher and Vincent Mosco, 229-248. Lanham: Lexington Books.

\section{About the author}

Sarah Waters

Sarah Waters is Senior Lecturer in French Studies at the University of Leeds. She has published two monographs: Social Movements in France (Palgrave/Macmillan 2003) and Between Republic and Market (Continuum, 2012). She is leading a research project funded by the Wellcome Trust on international workplace suicides:

http://www.leeds.ac.uk/arts/homepage/537/suicide voices trauma in the globalised workp $\underline{\text { lace }}$ 